REPORTS OF MORPHOLOGY
Official Journal of the Scientific Society of Anatomists,
Histologists, Embryologists and Topographic Anatomists
of Ukraine
journal homepage: https://morphology-journal.com

\title{
Macro-microscopic changes in the kidneys of the rats affected by methyl tertiary butyl ether in different time of the research
}

\section{Kuzmenko Y.Y., Shevchenko O.O., Nazar P.S., Haidai O.S.}

Bogomolets National Medical University, Kyiv, Ukraine

\section{ARTICLE INFO}

Received: 3 December, 2020

Accepted: 15 January 2021

UDC: $591.461: 57.044$

\section{CORRESPONDING AUTHOR}

e-mail: elenash150956@gmail.com Shevchenko O.O.
Methyl tert-butyl ether (MTBE) is a relatively new anthropogenic factor of environmental pollution. It is already known that it is an environmentally hazardous substance that has a toxic effect on the human body. The purpose of the research is to study the effect of MTBE on the structural organization of the kidneys of research animals. White outbred rats were involved into the research, which were treated with $500 \mathrm{mg} / \mathrm{kg}$ MTBE in an oil solution, which was administered intragastrically using a gastric catheter. Structural changes in the kidneys on the 3rd, 8th, 15th, 22nd and 60th day of the research were studied by means of light-optical and electron microscopy. The obtained material was processed statistically using the parametric Student's test and the nonparametric Kolmogorov-Smirnov test in accordance with the principles of variation statistics. During the runtime of the research, we have clearly defined the staging of changes in the structural organization of the kidney and the dependence of their severity on the duration of MTBE action. With short-term exposure (3, 8 and 15 day of the research), the weight of the kidneys and other organometric parameters do not differ from those in the control group. In the initial stages of MTBE action, we have observed reactive changes, which are clearly manifested in the structures of the filtration barrier (3rd day), and with an increase in the observation period (8th day) they spread to the epithelial cells of the proximal tubules. After 15 days of MTBE action, against the background of pronounced compensatory-adaptive events, we have noticed the development of dystrophicdestructive processes in the renal corpuscles and in the proximal tubules. There are structural signs of enhanced synthetic activity in the mesangial cells. On the 22nd day of the experiment, the morphometric index of the mass and linear dimensions of the kidneys increase in comparison with the control group. There are structural signs of atrophy and hypertrophy processes in the nephrons. There are progressive changes in the tubular apparatus of the kidneys in comparison with the previous period of the research. Long-term action of MTBE (60 days) causes further deepening of dystrophic and destructive changes in all parts of the nephron, which differ in intensity. It has been proved that MTBE has a negative effect on all structural components of the nephron, which leads to disorganization of the filtration and reabsorption of kidney apparatus and significant development of the connective tissue, which causes the development of sclerosis. Besides, it has been proved that MTBE has an apparent nephrotoxic effect and the degree of damage to the structural components of the kidney is determined by the duration of the body's contact with this toxic substance.

Key words: kidneys, Methyl tert-butyl ether, nephron.

\section{Introduction}

Environmental monitoring determines the deterioration of the environment and, primarily, due to environmental pollution by various chemical compounds [23, 26, 27]. Various factors of physical, chemical and biological genesis that constantly surround a person, directly negatively affect the organs and systems of the body, resulting in the development of various pathological conditions [3, 11, 12]. One of the global polluters, especially in modern cities, where transport infrastructure is significantly developed, is the exhaust gases of cars [4, 9]. Exhaust gases contain more than 300 different chemical compounds, most of which are toxic to the environment. One of the components of exhaust 
gases is Methyl tert-butyl ether (MTBE), which is used to increase the octane number of gasoline [1, 19, 24]. Many studies have been conducted on the effects of various toxic components of exhaust gases on humans and laboratory animals in the experiment $[13,14,15]$. MTBE is a relatively new anthropogenic factor, but it is already known that it is an environmentally hazardous substance that pollutes the environment $[8,17,28]$. The impact of MTBE on various organs and systems of humans and experimental animals has been studied in a few studies [7, 18]. It is established that MTBE has a negative effect on the body and causes the development of allergic, respiratory, cancer, lesions of the nervous system and a number of other pathological conditions [20, 28]. The selection of the bulk of chemical agents that enter the human body from the environment is carried out by the kidneys and therefore the kidneys are primarily a target for toxic chemicals [19, 21]. In addition, the kidneys are affected by the breakdown products of chemical components, which usually have a nephrotoxic effect. The effect of MTBE on the structure of the kidney in the experiment is practically not studied. Of particular importance is the study of the toxic effects of MTBE in the late stages of the experiment, because, as a rule, the human body is exposed to long-term exposure to toxic substances [2, 29].

The aim of the work is to study at the macroscopic, lightoptical and ultrastructural levels the morphological changes of the kidneys under the influence of MTBE at different terms of the experiment.

\section{Materials and methods}

The studies were performed on white outbred rats of adult age, which were kept in standard conditions vivarium of the National Medical University named after O.O.Bogomolets. Animals received $500 \mathrm{mg} / \mathrm{kg}$ MTBE daily in oil solution, which was administered intragastrically by gavage. The control group consisted of white outbred rats, which were also kept (similar to the experimental group) in standard vivarium conditions and were not exposed to MTBE.

The provisions of the "European Convention for the Protection of Vertebrate Animals Used for Experimental and Scientific Purposes" (Strasbourg, 1985) and the "General Ethical Principles for Animal Experiments", approved by the First National Congress on Bioethics, were followed in keeping, caring for and manipulating all animals. (Kyiv, 2001).

Animals were removed from the experiment under ether anesthesia 3, 8, 15, 22 and 60 days after its onset by decapitation according to the "Guidelines for the Removal of Animals from the Experiment" (1985) and the kidneys were immediately removed. In order to detect pathological changes of the kidneys at the macroscopic level, their appearance was determined, the mass and linear dimensions of the organ were measured. The material was fixed in $10 \%$ neutral formalin, paraffin sections were stained with hematoxylin and eosin.

For electron microscopic examination, $1 \mathrm{~mm} 3$ kidney pieces were removed. Processing of material for electron microscopic examination was carried out according to conventional methods. On the LKB III ultratome (Sweden), semi-thin and ultra-thin sections were obtained from the blocks. Semi-thin sections were stained with toluidine blue. Ultrathin sections were contrasted with $2 \%$ uranyl acetate solution and lead citrate. Samples were examined under an electron microscope PEM-125K at magnifications of 6-20 thousand, followed by photography.

\section{Results}

After 3 days of the experiment, the macroscopic structure of the kidneys, their weight and organometric parameters did not differ from those of the control group. According to the optical examination, it was found that on day 3 of the action of MTBE, cortex and medulla of the kidney were well differentiated. Vascular glomeruli were mostly the same size, unchanged, their capsule is not thickened. Urinary spaces are free. However, in the kidneys there were some local changes, manifested by focal edema, dilation of the lumen of blood vessels, especially the venular, with accumulation of blood cells, plethora of individual glomeruli and focal edema of the tubular epithelium. At the ultrastructural level, changes were detected in all components of the nephron. The cytoplasm of endothelial capillaries of glomeruli of high electron density, swollen. In endothelial cells, the zonation of the cytoplasm is preserved: the zone of the perikaryon and the delicate peripheral areas are determined, in which separate thickened cytoplasmic islands protruding into the lumen of the vessel are observed. Organelles of the synthetic apparatus are located in the area of the perikaryon and thickened cytoplasmic islets. The microvesicular transport system is poorly developed. Micropinocytic vesicles are filled with electronically transparent contents. Thinned peripheral areas of endotheliocytes contain open fenestra, the size of which varies. The basement membrane is predominantly of moderate electron density, without significant changes (Fig. 1). Cytopodia

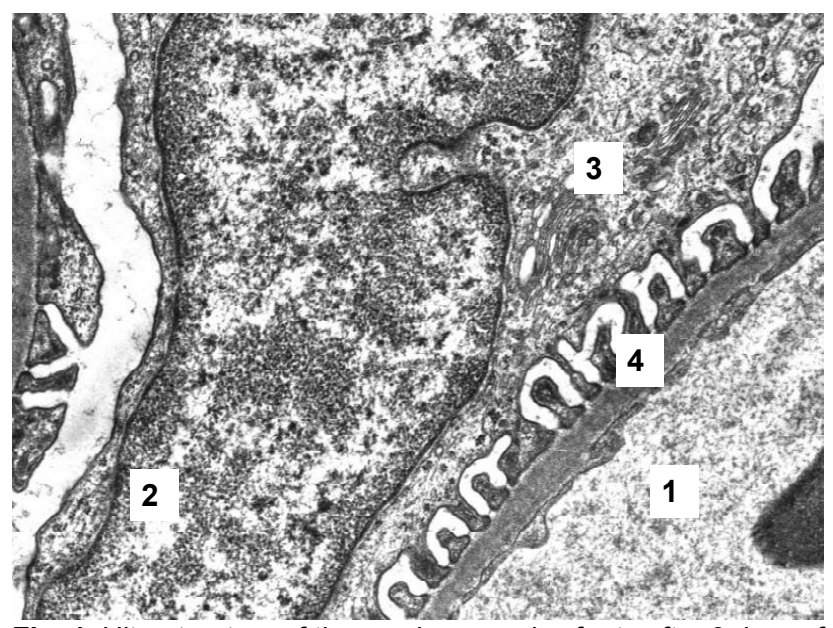

Fig. 1. Ultrastructure of the renal corpuscle of rats after 3 days of MTBE use. Gloss of the glomerular capillary (1). Nucleus (2), Golgi complex (3) in podocytes. Glomerular basement membrane (4). $\mathrm{x} 18000$. 
of podocytes are variable in shape and size: short-shortened cytopodia are determined by length, other elongated, located at different angles to the basement membrane. In many cytopodia, small electron-dense inclusions are identified at the basal end. Diaphragms are visualized in almost all filtration slits.

The ultrastructure of mesangial cells indicates the activation of biosynthetic processes, signs of which are hypertrophy of their organelles, primarily the tubules of the endoplasmic reticulum.

The brush border was disturbed in the proximal tortuous tubules of the nephron. The microvilli that form it locally lost their parallel orientation, fragmented, and desquamed into the lumen of the tubule, as a result of which the areas of the apical surface of epitheliocytes sometimes did not have such a border. Epitheliocytes are mosaic by ultrastructural structure. Electronically illuminated cells with varying degrees of edema are observed. The consequence of significant violations of the excretion of water from the cells is the formation of sequestration with edematous fluid, obstructing the lumen of these tubules. In other epitheliocytes there is an accumulation of fine material and, depending on its compaction, the cells vary in electron density. A small number of apoptotic epitheliocytes are identified, which have already lost contact with other cells and have been pushed into the lumen of the tubule.

On the 8 day of the experiment, the macroscopic structure of the kidneys, their weight and organometric parameters did not change and did not differ from those of the control group. At the optical level, the glomeruli are mostly the same size, in some there was an expansion of the urinary space at one of the poles. The glomerular capsule is not thickened. Glomerular capillaries are full-blooded. In some hypertrophied glomeruli there is hypercellularity and expansion of mesangial spaces. More significant changes were found in the tubular apparatus of the kidneys. In the cortex, in the proximal and distal tubules of the kidneys there is granular and hydropic dystrophy of epitheliocytes, their desquamation into the lumen of the tubules and the destruction of the basement membrane in some places. At the ultrastructural level, cells with slightly increased electron density of nuclei and cytoplasm predominate among glomerular capillary endothelial cells. Peripheral areas, as a rule, are thinned and separate microclasmatous outgrowths are noted. Non-diaphragm fenestrae are uneven, sometimes their length is quite significant, which gives reason to think about the difference in endothelial cells. Podocytes undergo further changes. The number of organelles in the body and cytotrabeculae decreases slightly compared to the previous observation period. Cytopodia of podocytes are characterized by the accumulation of electrondense material, which occupies a significant area. The largest changes among the structures of the renal corpuscle undergo mesangial cells, the number of which is increasing. Two mesangial cells are sometimes observed in the bifurcations of capillary loops. Some mesangiocytes have ultrastructural signs of increased biosynthetic activity. They contain a nucleus with chromatin and nucleolus evenly distributed throughout the karyoplasm, a significant number of ribosomes, endoplasmic reticulum tubules, large mitochondria with a transparent matrix and cristae, microfibrils. Changes in proximal tubules of a nephron amplify. Dark cells are common among epitheliocytes. The microvilli on the apical surface are mostly fragmented, partially desquamated, and the number of secretory vesicles and associated granules is reduced. At the same time, light cells are observed, in the cytoplasm of which are placed single mitochondria, tubules of the endoplasmic reticulum, ribosomes, secretory granules, which are sometimes grouped, forming structures resembling residual bodies in dark cells. The distal tubules, in which epitheliocytes of moderate electron density are widespread, suffer to a lesser extent.

On the 15 day of the experiment, the macroscopic structure of the kidneys, their mass and organometric parameters did not differ statistically from those of previous terms and the control group. At the optical level, structural changes in some renal corpuscles, represented by the phenomena of hypertrophy, as well as atrophy and edema of the glomeruli, were determined. At the electron microscopic level, the structural components of the nephron became more mosaic. Part of the body retains the integrity of the structural components and signs of functional activity. But even in such bodies, the lumens of the capillaries are partially filled with erythrocytes and coagulated plasma, which can lead to a slowing of the flow rate. In cytotrabeculae the number of organelles is insignificant, sometimes they have electronically dense deposits. Similar deposits are found in individual cytopodia of different sizes. Along with renal corpuscles with ultrastructural signs of functional activity, corpuscles are observed in the cells of which destructivedystrophic processes predominate. The lumen of the glomerular capillaries of such bodies is unevenly expanded, deformed, sometimes shaped blood elements and felt-like accumulations are determined.

In the electron-dense cytoplasm of endothelial cells, a small number of organelles, especially mitochondria, are detected. Thinned peripheral areas of the endothelial cell cytoplasm are fragmented in places and desquamated into the lumen of the capillary. The areas between the fragments of the cytoplasm of endothelial cells are filled with finegrained electron-dense contents, sometimes there is the formation of growths of the basal surface of endotheliocytes, which are immersed in the periendothelial space or surrounded by the basement membrane. Edema of the periendothelial space is determined, which is filled with finegrained substance of medium electron density, as a result of which the basal surface of endothelial cells is located at a certain distance from the basement membrane, which in such places is thickened, expanded, heterogeneous in structure, compacted. In other areas, the basement membrane is homogeneous and formed by a solid material 
of high electron density. Significant structural changes are defined in podocytes. Cytotrabeculae are different in size, uneven in electron density; organelles are practically absent in the cytoplasm of cytotrabecula. In some podocytes the phenomena of necrosis are determined and they are desquamated into the lumen of the nephron capsule. The number of cytopodia decreases, they are irregularly located along the basement membrane, variable in size and shape; shortened, thickened cytopodia with an enlightened cytoplasmic matrix are determined. Other cytopodia are long, thin, electronically dense, located at different angles to the basement membrane, sometimes cytopodia are closely adjacent to the basement membrane. Filtration slits are located irregularly, of various sizes; some of them are covered with thickened filter diaphragms. Filtration slits are determined, where the destruction of their filtration membranes is determined. Mesangial cells contain a functionally active nucleus with uniformly distributed chromatin, around which most mitochondria are located. The processes of mesangial cells are filled with ribosomes, polysomes, tubules of the endoplasmic reticulum, microfibrils. In the proximal tubules, a significant mosaic of the ultrastructure of the epitheliocytes lining them is determined. There are tubules, the lumens of which are filled with microvilli that are close to each other, until they merge. In the apical part of epitheliocytes there are typical vesicles, secretory granules, primary lysosomes. Below, to the basal surface of the nucleus with a fairly evenly distributed chromatin, numerous mitochondria, lipid-loaded and large lysosomes with lamellar or uneven electron seals. Mitochondria in these cells have clearly structured outer membranes and cristae. All this indicates their active functional activity. However, there are tubules, where the microvilli of the bristle border are not dense, are at different stages of fragmentation and desquamation. The lumens of the proximal tubules are densely filled with sequesters with denatured proteins and edema fluid. As a rule, in cells with the changed microvilli the reduced quantity of organelles is defined, the cytoplasm is electronically condensed. The pycnomorphic nucleus is located in some dark cells, and the epitheliocytes themselves lose lateral contacts and separate from each other. There are also tubules, where the cells changed by the dark type are reduced in size and in the form of small electronically dense clusters are located in the lumen of the tubules. Such changes indicate an apoptotic pathway of epithelial cell death. In this case, the processes of apoptosis in the epitheliocytes of the proximal convoluted tubules occur asynchronously, a sign of which is the presence of cells at different stages of apoptosis and the appearance of apoptotic cells. A feature of the ultrastructure of epithelial cells of the proximal tubules in this period of the experiment is the presence of irregularly shaped structures, the electron density of the matrix which varies from transparent to moderately compacted, regardless of the degree of changes in the cells. These structures are residual bodies - the product of lysosomal dysfunction, which accumulate and are not disposed of.

On the 22 day of the experiment there is an increase in the organometric parameters of the kidneys. Thus, the mass of the left kidney increases by $24 \%$, and the right by $22 \%$ compared with the control group. Changes in the linear size of the kidney have a similar direction: the length, width, thickness of the organ are significantly increased in comparison with similar parameters of the control group. The histological structure of the glomeruli is not significantly changed in comparison with the previous terms of observation. Both atrophied and hypertrophied glomeruli are observed. Glomerular capillaries are dilated, full-blooded. In some glomeruli, the urinary space is dilated and filled with cellular detritus, which consists of endothelial and mesangial cells. Moderate sclerosis is observed around the capsule of individual glomeruli. The tubular apparatus of the kidneys undergoes more pronounced changes compared to the previous observation period. Individual tubules retain their structure, they contain cells in which the nuclei are almost not visualized, the cytoplasm of cells - with signs of granular and hydropic dystrophy. In many tubules, the lumen is completely filled with conglomerates of desquamated cells and cellular detritus. The boundaries of the vast majority of tubules are not defined. There is a pronounced swelling of the interstitium, there are plasma cells and fibroblasts. According to ultrastructural analysis, the destructive-dystrophic changes that develop in the renal corpuscles have a different direction than in previous terms of the experiment. There is no dark, apoptotically altered endothelial cells and podocytes. Peripheral areas of endothelial cells are mostly thinned, sometimes to the thickness of two membranes. Fenestra in thin areas are uneven and vary in length. In some places, there are wide loci between adjacent fragments of the cytoplasm, as well as diaphragmatic fenestrae, which appear in pathological conditions. The prevalence of microclasmatous growths on the luminal surface of endothelial cells and in the lumen of capillaries, as well as large sequesters with edematous fluid (Fig. 2) is noteworthy.

Podocytes change according to the light type: nuclei predominate, where chromatin forms clusters of insignificant electron density, and karyoplasm is electronically transparent. In the same enlightened cytoplasm are organelles, the number of which is reduced compared to the previous term of the experiment. Cytopodia are diverse in shape and ultrastructure. Some of them retain their characteristic leglike shape and typical diaphragmatic fissures, and other cytopodia acquire an elongated shape or protrude into the urinary space, spreading along the glomerular membrane. A significant number of mesangial cells are identified, which are located at the bifurcations of capillary loops and contain 1-2 large nuclei, which may be an indirect sign of polyploidization. Well-developed organelles of the synthetic apparatus (ribosomes, polysomes, tubules of the granular endoplasmic reticulum) and mitochondria indicate active functional activity of these cells. This fact confirms the 


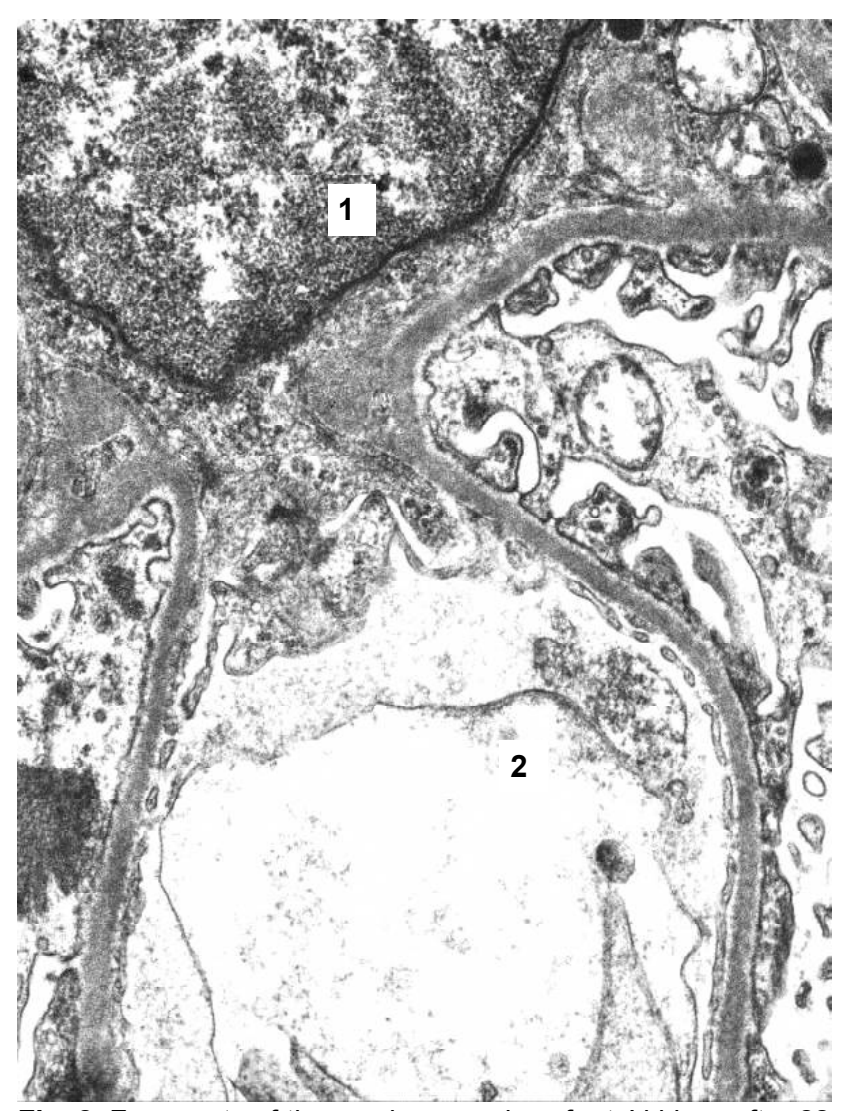

Fig. 2. Fragments of the renal corpuscles of rats' kidney after 22 days of MTBE use. Mesangial cells (1). Blisters of edema in the lumen of the capillaries (2). x8000.

increase in the amount of connective tissue in the glomeruli.

At the same time, mesangial cells with signs of dystrophic and destructive processes are observed. Such cells contain swollen tubules of the endoplasmic reticulum and mitochondria with local lysis of the matrix and cristae. On the surface of these cells there are microclasmatous growths and sequesters with edematous fluid, which protrude into the subendothelial layer, separating endothelial cells from the basement membrane. The ultrastructure of the proximal tubules after 22 days of MTBE action differs from that observed after 15 days. Most epitheliocytes have signs of varying degrees of dystrophic and destructive processes that extend to almost all cellular structures. Microvilli are usually delicate and often merge with each other or along the entire length, or in fragments. In some tubules their detachment from an apical surface is noted that leads to exposure of the last. Under the microvilli in the apical part of the cytoplasm there is a significant number of elongated or rounded secretory granules and primary lysosomes, most of which are electronically sealed. At the same time, the number of secondary and tertiary lysosomes in the central and basal parts of the cytoplasm is sharply reduced. Vacuoles with electronically transparent or finely dispersed, moderate electron density content are mainly observed.
After 60 days of MTBE use, the renal mass and their linear size become statistically significantly smaller than after 22 days of the experiment, but larger than in the control group. Microscopic examination draws attention to the appearance of sclerotic changes, which was not characteristic of rats of previous groups. Connective tissue growth is observed around the capsule of glomeruli, individual tubules and vessels. It should be noted that the glomeruli in this period of the experiment are significantly reduced in size, some atrophied and sclerosed, there is a small number of hypertrophied glomeruli. The variability of morphological changes in renal corpuscles attracts attention: structural manifestations of both hypertrophy and atrophy are revealed.

At the electron microscopic level, the lumens of the glomerular blood capillaries are usually dilated, often filled with shaped elements of blood, among which are identified cells at different stages of apoptosis. The endothelial cells of the blood capillaries of the glomeruli suffer significant damage: most of these cells are modified in the dark type with electronically compacted pycnomorphic nuclei. In the area around the nucleus, where most general-purpose organelles are located, it is difficult to distinguish individual structures. The peripheral parts of the cytoplasm of endothelial cells are unevenly thinned: significantly thinner

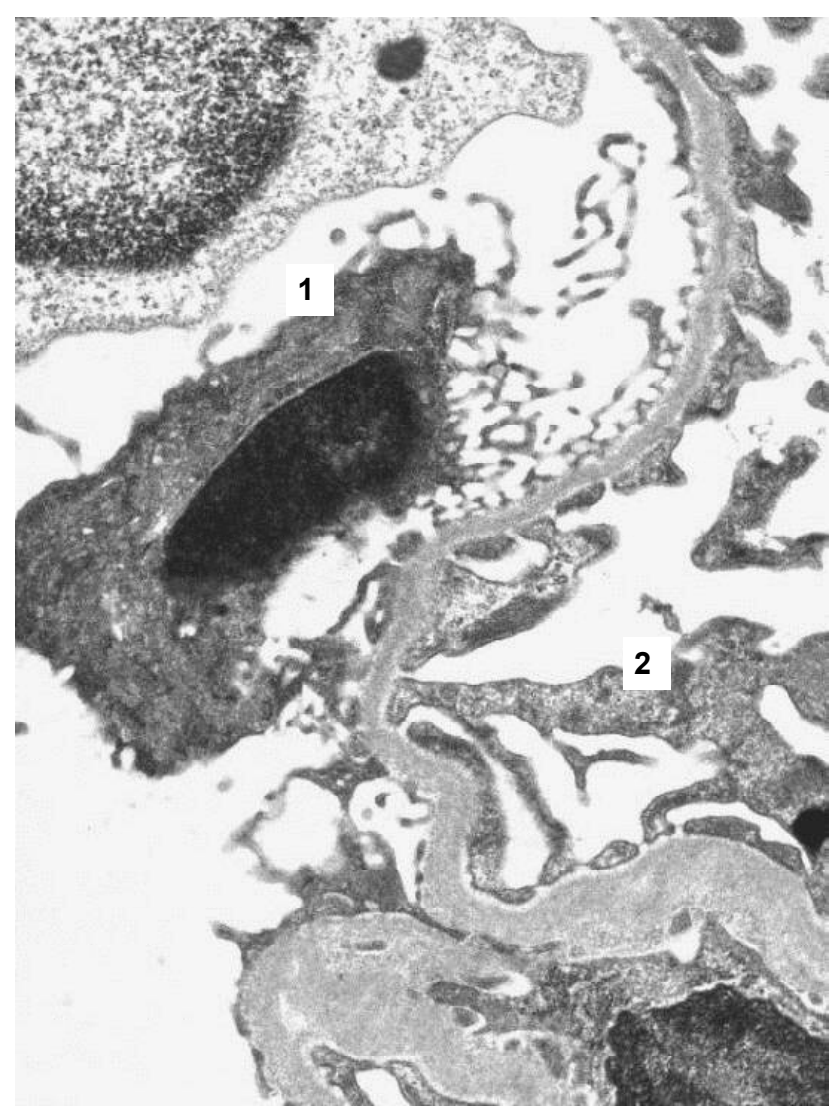

Fig. 3. Fragments of the renal corpuscles of rats' kidney after 60 days of MTBE use. Electronically sealed endothelial cells (1). Podocytes of moderate electron density (2). x10000. 
areas of endotheliocytes are identified, in which the fenestrae disappear, and in other areas the size of the fenestrae reaches larger sizes. These processes occur against the background of marked destruction of other areas of endothelial cells, the cytoplasm of which acquires increased electron density, loses contact with the basement membrane and is desquamated (Fig. 3). The detected morphological changes indicate the development of apoptosis in the endotheliocytes of the blood capillaries of the glomeruli of the nephron. Deepened changes in the glomerular basement membrane. The areas where it connects endothelial cells and podocytes are thickened in places, locally destroyed in places. The mosaic structure of structural changes in podocytes is determined: some podocytes have a cytoplasm of moderate electron density, and in others the increase of electron density of cytoplasm in both trabeculae and cytopodia is determined. Dark podocytes usually had a pycnomorphic nucleus and destructively altered mitochondria.

Podocytes with medium electron density cytoplasm and electronically compacted cells are partially fragmented and desquamated into the lumen of the glomerular capsule. In some areas, cytopodia increase in size, acquire an irregular shape, thicken, are closely spaced, as a result of which the filtration gaps disappear between them. Filtration slits vary in size; most of them are covered with medium electron density filtration diaphragms, but in some places filtration diaphragms are not detected. Mesangial cells have structural signs of increased functional activity. In these cells large nuclei are defined, the nucleolemma of which forms numerous deep intussusception. The nuclei are quite electronically dense, heterochromatin in the form of different sized depths is concentrated near the inner leaf of the nucleolemma. In the nucleus there is a large electrondense nucleolus. The cytoplasm of mesangial cells of high electron density with a significant number of ribosomes, polysomes, fibrous structures. Numerous mitochondria oval or elongated with well-developed cristae. A significant number of tubules of granular endoplasmic reticulum filled with medium electron density is determined. The phenomena of hyperplasia and hypertrophy of the Golgi complex are observed. Microfilaments are detected in the cytoplasm of mesangial cells. Activation of the biosynthetic activity of mesangial cells leads to an increase in the volume of the mesangial matrix and an increase in the content of fine-fiber structures in it, so that the processes of these cells appear to be walled up in the mesangium. Another consequence of significant processes of connective tissue biosynthesis is a significant thickening of basement membranes in areas of capillary bifurcations, as well as a large number of collagen fibers that accumulate around the renal corpuscles and in the interstitial space in the form of separate fibers or massive bundles. Epithelial cells of the proximal tubules have signs of dystrophic and destructive changes. Cells, as a rule, acquire an irregular shape, lose their inherent topography, the nuclei are often displaced to the apical surface. Epitheliocytes with a cytoplasm of moderate electron density contain nuclei with uniformly distributed chromatin, but even in such cells the number of all organelles is reduced: both those involved in reabsorption (dense granules, lysosomes), and organelles of biosynthesis. Electronically compacted cells are observed, in which the number of organelles is also reduced, and the cytoplasm is filled with a fine substance, probably of protein origin. This substance can form local clusters or be located throughout the cytoplasm. The nuclei in such cells are pycnomorphic. Cells where this electronically dense substance displaces organelles and completely fills the entire cytoplasm lose their bond with each other, decrease in size, change shape, and take on the appearance of apoptotic cells.

\section{Discussion}

The study showed that the kidney is a very sensitive organ to MTBE. The dynamics of the experiment clearly revealed the stages of change and the dependence of their manifestations on the duration of action of this substance.

In the early stages of the experiment (3, 8 and 15 days) MTBE does not adversely affect kidney mass and its linear size. Increasing the duration of MTBE use (up to 22 days) causes changes in all the parameters studied, for example: the mass of the kidneys increases, respectively, increases its linear size compared to the control group. Long-term (60 days) action of MTBE led to a decrease in kidney mass and its linear size compared to the previous period of the experiment, but, nevertheless, the indicators did not reach the control values.

At the structural level, in the early stages (3 days) of MTBE action, reactive changes were detected, which were more clearly manifested in the structures of the filtration barrier.

Increasing the observation period to 8 days led to more pronounced changes, which extended to the epitheliocytes of the tubules, mainly proximal, which are characterized by the presence of cells at different stages of apoptosis.

After 15 days of the experiment, against the background of pronounced compensatory-adaptive changes, the development of dystrophic-destructive processes in both renal corpuscles and proximal tubules is noted. The main direction of changes in the cells of these parts of the nephron are changes in the dark type, ie apoptosis. Distal tubules, as in previous periods of the experiment, are more resistant to MTBE, they had no apoptotically altered epitheliocytes.

After 22 days of MTBE use, the renal ultrastructure differed from that observed after 15 days of MTBE. There are no endotheliocytes and podocytes in the renal corpuscles with signs of increased biosynthetic activity, which were distributed in the previous period. Changes in these cells take on a different direction: light cells predominate, while dark cells disappear, which is most likely due to their death. This is confirmed by the absence 
of the smallest, atrophic bodies. Fusion and flattening of podocytes leads to a decrease in the number of diaphragm slits, which leads to a decrease in filtration processes. Increased functional activity of mesangial cells, which increased throughout the experiment, contributes to the deterioration of these processes due to increased connective tissue in the renal corpuscles. Electronically enlightened, swollen epitheliocytes are common in the proximal tubules, whereas dark cells are not observed. Dystrophic and destructive changes vary in severity in different epitheliocytes and extend to almost all cellular structures. The distal tubules do not show a significant deepening of ultrastructural changes, the greatest damage is suffered by basal membrane extrusion.

According to Y.I. Fedonyuk and V.V. Sikora [25] under the influence of heavy metal salts, the structural components of the renal nephron during the month of the experiment do not undergo significant changes. In the late stages of the experiment ( 60 days of MTBE action) compensatoryadaptive features apply only to a small number of cellular components of the nephron. Dystrophic and destructive changes, which vary in severity, predominate in all parts of the nephron. The most vulnerable to long-term action of MTBE are podocytes in the renal corpuscles and epitheliocytes of the proximal tubules. In cases where the damage becomes significant, there is atrophy of the renal corpuscles and devastation of the tubules, which leads to a decrease in their number. Increased activity throughout the experiment of cells that produce intercellular substance and, in particular, collagen fibers, leads to the development of renal fibrosis and the formation of severe renal sclerosis.

Similar dynamics of morphological changes of the gastric mucosa, cerebral cortex and thymus under the action of large doses of MTBE in similar terms of the experiment

\section{References}

[1]Alkazmi, L.M.M., Al-Sahhaf, Z.Y., Malak, H.A., \& Abulreesh, H.H. (2017). Effects of methyl Tert-butil Ether (MTBE) on the Mucosal Immunity in the Small Intestine of the White Albino Mice. Annual Research and Review in Biology, 15(4), 1-11. doi: 10.9734/ARRB/2017/35016

[2] Alishahi, S., Zendeh-Boodi, Z., \& Saadat, M. (2020). Genotoxicity effect of methyl-tertiary butyl ether on rat lymphocytes using comet assay. EXCLI Journal, 19, 668-670. https://doi.org/ 10.17179/excli2020-2159

[3] Al Fakih, M.A.M., Al-Gabr, H.M. (2019). The toxic effect of methyl tertiary butyl ether (MTBE) on the mice weight and kidney. An. International Multidisciplinary Research e-Journal, 5, 29-39.

[4] Badr, A.A., Saadat, I. \& Saadat, M. (2016). Study of liver function and expression of some detoxification genes in the male rats exposed to methyl-tertiary butyl ether. The Egyptian of Medical Human Genetics, 17(4), 325-329. doi: 10.1016/ j.ejmhg.2015.10.002

[5] Cherkasov, V.G., Dzevulska, I.V., \& Kovalchuk, O.I. (2010). Стан гемомікроциркуляторного русла слизової оболонки шлунка щурів під дією метилтретбутилового ефіру [The state of the hemomicrocirculatory tract of the gastric mucosa of rats under the action of methyl tert-butyl ether]. Український морфологічний альманах - Ukrainian Morphological is described in other studies $[5,6,16]$. The same dynamics of morphological changes in the structural components of the kidney under the influence of salts of heavy metals are determined after 2 months of the experiment [10]. According to the authors, the degree of pathological changes in the structural components of the kidney depends on the duration of heavy metals salts action on the kidneys. Under the influence of alcohol, similar structural lesions of nephron components are determined [22]. Thus, various toxic chemicals have a pronounced nephrotoxic effect, and the degree of damage to the structural components of the kidney is determined by the duration of toxic effects on the body.

In the future it is planned to study the histochemical changes in the mesangial cells of the renal corpuscle of the nephron in order to identify substances that are most actively synthesized by cells under the influence of different doses of MTBE. These studies will help determine which macromolecules accumulate in the glomerular basement membrane and in the mesangial matrix, which leads to their thickening and, thus, determines the disruption of filtration processes that occur through the filtration barrier of the renal nephron.

\section{Conclusions}

Thus, the study showed that MTBE has a pronounced nephrotoxic effect. MTBE adversely affects all structural components of the nephron, which leads to disorganization of the filtration and reabsorption apparatus of the kidney and the significant development of connective tissue, which causes sclerosis. The degree of damage to the structural components of the kidney by MTBE is determined by the duration of contact of the body with this toxic substance.

Almanac, 8(3), 149-151.

[6] Cherkasov, V.G., Kovalchuk, O.I., Kerechanin, I.V., \& Parakhin, А.А. (2009). Ультраструктурні прояви апоптогенного впливу метилтретбутилового ефріру на клітини слизової оболонки шлунка, тимуса та кори півкуль великого мозку [Ultrastructural manifestations of apoptogenic effect of methyl tert-butyl ether on cells of the gastric mucosa, thymus and cerebral hemispheres] Актуальні проблеми функціональної морфології та інтегративної антропології "Прикладні аспекти морфології" - Actual problems of functional morphology and integrative anthropology "Applied aspects of morphology". Вінниця: ВНMУ - Vinnytsia: VNMU.

[7] Kuzmenko, Yu.Yu., Stechenko, L.O., Shevchenko, O.O., \& Kuftireva, T.P. (2009). Мофрофункціональні зміни гемомікроциркуляторного русла нирки в ранні терміни дії метилтретбутилового edpipy [Mophrofunctional changes of a hemomicrocirculatory channel of a kidney in early terms of action of methyl tert-butyl ether]. Український медичний альманах - Ukrainian Medical Almanac, 7(1), 48-56.

[8] Lazarev, K.P., Zhukova, A.A., \& Lyashenko, O.I. (2006). Сравнительная морфометрическая характеристика отделов нефрона единственной почки при воздействии алкоголя и эноанта в эксперименте [Comparative morphometric 
characteristics of the nephron divisions of a single kidney under the influence of alcohol and enoant in the experiment]. Таврический медико-биологический вестник Tavrichesky Medical and Biological Bulletin, 9(3), 1, 93-97.

[9] Meiramkulova K.S., \& Chekushev D.V. (2016). Анализ содержания летучих органических соединений в атмосферном воздухе придорожного пространства Астаны [Analysis of the content of volatile organic compounds in the atmospheric air of the roadside space of Astana]. Вестник Российского университета дружбы народов. Серия Экология и безопасность жизнедеятельности - Bulletin of the Peoples' Friendship University of Russia. Series Ecology and Life Safety, 3, 93-97.

[10] Milovanova, M.I. (2006). Вплив солей алюмінію і свинцю на морфологічний стан нирок і печінки стресованих тварин [Influence of aluminum and lead salts on the morphological state of kidneys and liver of stressed animals]. Клінічна анатомія та оперативна хірургія - Clinical Anatomy and Operative Surgery, 2, 43-44.

[11] Mohammadzadeh, B.S., Mashinchian, M.A., Sharifpour I., Jamili Sh., \& Ghavam, M.P. (2017). The in vivo effect of methyl-butyl ether on liver, gills, and kidney tissues of Ruitilus caspicus. Iranian Journal of Fisheries Sciences, 17(4), 821-834. doi: 10.22092/ijfs.2018.119526

[12] Mohammadtaghi, V., Rafatullah, M., \& Salamantinia, B. (2017). Absorption studies of methyl-tert-butyl ether from environment. Separation and Purification Reviews, 4, 273-290. https:// doi.org/10.1080/15422119.2016.1270966

[13] Momen, A., Valipour, M., Maghami, P., \& Ariaeenejad, S. (2019). Lack of antioxidant effect of selenium on interaction of methyl tert-butyl ether with Cytochrome. Biomacromolecular Journal, 5(2), 129-139. ISSN: 7280-2423.

[14] Najdegerami, I.H., Hosseinzadeh, G., Sheikh-Hasani, V., MoosaviMovahedi, F., Maghami, P., Sheibani, N., \& Moosavi-Movahedi, A.A. (2019). Dual effect of Coffeine and Curcumin as Antioxidants on Human Hemoglobin in the Presence of Methyl Tert-butyl Ether (MTBE). Biomacromolecular Journal, 5(1), 58-71.

[15] Najdegerami, I.H., Maghami, P., \& Sheikh-Hasani, V. (2016). Antichaperone activity and heme degradation effect of methyltert-butyl ether on normal and diabetic hemoglobins. Molecular Recognition, 30(5), 25-34. https://doi.org/10.1002/jmr.2596

[16] Parakhin, A.A., Dupliy, I.S. (2009). Ультраструктурні зміни міжнейрональних зв'язків кори півкуль великого мозку щура під впливом метилтретбутилового ефіру [Ultrastructural changes of interneuronal connections of the cerebral cortex of rats under the influence of methyl tert-butyl ether]. Науковий вісник Національного медичного універcumeту імені О.О.Богомольця - Scientific Bulletin of the Bogomolets National Medical University, 4, 50-55.

[17] Paustovsky, Y.O. (2008). Еколого-токсикологічна оцінка глобального забруднювача довкілля - метилтретбутилового ефрipy (стан та перспективи) [Ecological and toxicological assessment of the global environmental pollutant - methyl tert-butyl ether (status and prospects)]. Пріоритетні проблеми гігієни праці, професійної та виробничо-зумовленої захворюваності в Україні - Priority problems of occupational health, occupational and occupational diseases in Ukraine. Київ: НМК - Kyiv: NMK.

[18] Pongkua, W., Dolphen, R., \& Thiravetyan, P. (2018). Effect of functional groups of biochars and their ash content on gaseous methyl-tert-butyl ether removal. Colloids and Surfaces A: Physicochemical and Engineering Aspects, 558, 531-537. https://doi.org/10.1016/j.colsurfa.2018.09.018
[19] Saaedi, A., Omidi, M., Khoshnoud, M.J., \& Mohammadi-Bardbori, A. (2017). Exposure to methyl tert-butyl ether (MTBE) is associated with mitochondrial dysfunction in rat. Xenobiotica, 47(5), 423-430. doi: 10.3109/00498254.2015.1125040

[20] Sarhan, O., Jain, A., Mutwally, H., Osman, G., \& Jung S. (2020). Impact effect of methyl tertiary-butyl ether "Twelve months vapor inhalation study in rats". Biology, 9(1), 1-19., https:// doi.org/10.3390/biology9010002

[21] Saitfutdinov, R.G., \& Trifonova, E.V. (2010). Острая токсичность метил-трет-бутилового эфира [Acute toxicity of methyl tert-butyl ether]. Казанский медицинский журнал Kazan Medical Journal, 91(3), 351-353.

[22] Shutka, B.V., \& Ivanochko, V.M. (2004). Морфологічні аспекти стану компонентів клубочкового фрільтра нирок при алкоголізації міцними алкогольними напоями та сурогатами спирту [Morphological aspects of the state of the components of the glomerular filter of the kidneys during alcoholization with strong alcoholic beverages and alcohol surrogates]. Клінічна анатомія та оперативна хірургія Clinical Anatomy and Operative Surgery, 3(3), 25-28.

[23] Tang, Y., Ren, Q., Wen, Q., Yu, C., Xie, X., Hu, Q., \& Du, Y. (2019). Effect of methyl tert-butyl ether on adipogenesis and glucose metabolism in vitro and in vivo. Journal of Environmental Sciences, 85, 208-219. https://doi.org/10.1016/ j.jes.2019.06.015

[24] Taranenko, N.A., Meshchakova, N.M., \& Zhurba, O.M. (2018). Гигиеническая оценка воздуха рабочей зоны химических производств бутиловых спиртов и метил-трет-бутилового эфира [Hygienic assessment of the air in the working area of the chemical production of butyl alcohols and methyl tert-butyl ether]. Гигиена и санитария - Hygiene \& Sanitation, 97(9), 835-939. https://doi.org/10.47470/0016-9900-2018-979-835-839

[25] Fedonyuk, Y.I., Sikora, V.V. (2006). Гістоморфометрія нирки в умовах споживання солей важких металів [Kidney histomorphometry in the conditions of consumption of salts of heavy metals]. Таврический медико-биологический вестник - Tavrichesky Medical and Biological Bulletin, 9(3), 1, 165-167.

[26] Ward, M.H., Jones, R.R., Brender, J.D., de Kok, T.M., Weyer, P.J., Nolan, B.T. ... Van Breda, S.G. (2018). Drinking Water Nitrate and Human Health: An Updated Review. Int. J. Environ. Res. Public. Health, 15(7), 1557. doi: 10.3390/ijerph15071557

[27] Xie, G., Hong, W., Zhou, L., Yang, X., Huang, H., Wu, D. ... Liu, J. (2017). An investigation of methyl tert-butyl ether-induced cytotoxity and protein profile in Chinese hamster ovary cells. Molecular Medicine Reports, 16(6), 8595-8604. https:// doi.org/10.3892/mmr.2017.7761

[28] Yavorovsky, O.P., Paustovsky, Y.O., \& Drobotenko, V.A. (2007). Гігієнічна оцінка умов праці та стан здоров'я робітників, зайнятих виготовленням метилтретбутилового ефіру на Лисичанському НПЗ [Hygienic assessment of working conditions and health of workers engaged in the production of methyl tert-butyl ether at the Lysychansk refinery]. Довкілля та здоров'я - Environment and Health, 40(1), 34-38.

[29] Yavorovsky, O.P., Paustovsky, Y.O., Tkachyshyn, V.S., \& Volodyj, M.O. (2012). Особливості впливу метилтретбутилового ефіру на організм людини та шляхи профілактики професійних отруєнь цією речовиною [Features of the effect of methyl tert-butyl ether on the human body and ways to prevent occupational poisoning by this substance]. Пpoблеми екології та медицини - Problems of Ecology and Medicine, 16(3-4), 34-36. 
МАКРО-МІКРОСКОПІЧНІ ЗМІНИ НИРОК ЩУРІВ ПІД ВПЛИВОМ МЕТИЛТРЕТБУТИЛОВОГО ЕФІРУ В РІЗНІ ТЕРМІНИ ЕКСПЕРИМЕНТУ

Кузьменко Ю.Ю., Шевченко О.О., Назар П.С., Гайдай О.С

Метилтретбутиловий ефрір (МТБЕ) - це відносно новий антропогений чинник забруднення навколишнього середовища. Вже відомо, що він є екологічно небезпечною речовиною, котра токсично впливає на організм людини. Метою дослідження є вивчення впливу МТБЕ на структурну організацію нирок експериментальних тварин. Дослідження виконано на білих безпородних щурах, що отримували 500 мг/кг МТБЕ в олійному розчині, який вводили внутрішньошлунково за допомогою зонда. Методами світлооптичної та електронної мікроскопії вивчали структурні зміни нирок на 3, 8, 15, 22 та 60-ту добу експерименту. У динаміці експерименту чітко визначена стадійність змін структурної організації нирки та залежність їх виразності від терміну дії цієї речовини. При короткотривалій дії (3, 8 та 15 доби експерименту) маса нирок та інші органометричні показники не відрізняються від аналогічних контрольної групи. На ранніх етапах дії МТБЕ виявляються реактивні зміни в структурах фрільтраційного бар'єру (3 доби), які при збільшенні терміну спостережень (8 діб) поширюються і на епітеліоцити проксимальних канальців. Через 15 діб дії МТБЕ на тлі виразних компенсаторно-пристосувальних змін відмічається розвиток дистрофрічно-деструктивних процесів у ниркових тільцях і в проксимальних канальцях. В мезенгіальних клітинах виявляються структурні ознаки посиленої синтетичної активності. На 22 добу експерименту морфометричні показники маси та лінійних розмірів нирок збільщуються порівняно з контрольною групою. В нефронах визначаються структурні ознаки як процесів атрофії, так і гіпертрофії. Канальцевий апарат нирок зазнає прогресуючих змін у порівнянні із попереднім терміном експерименту. Довготривала дія МТБЕ (60 діб) викликає подальше поглиблення дистрофічних та деструктивних змін в усіх відділах нефрону, які варіюють за проявами. Визначено, що МТБЕ негативно впливає на всі структурні компоненти нефрону, що призводить до дезорганізації фрільтраційного та реабсорбційного апарату нирки і значного розвитку сполучної тканини, що обумовлює явища склерозу. Доведено, метилтретбутиловий ефір має виражений нефротоксичний ефект і ступінь ураження структурних компонентів нирки визначається тривалістю контакту організму з цією токсичною речовиною.

Ключові слова: нирки, метилтретбутиловий ефрір, нефрон. 